\title{
Laparoscopic partial cecum resection in appendiceal intussusception
}

\author{
Serkan Zenger ${ }^{1}$, Çağrı Bilgiç ${ }^{1}$, Dursun Buğra ${ }^{1,2}$ \\ ${ }^{1}$ Clinic of General Surgery, VKV American Hospital, Istanbul, Turkey \\ ${ }^{2}$ Department of General Surgery, Koç University School of Medicine, Istanbul, Turkey
}

\begin{abstract}
Appendiceal intussusception (AI) is a difficult disease to diagnose. Various features of the disease were analyzed in a 35-year-old female patient admitted with abdominal pain and diagnosed with Al. The diagnosis was made with colonoscopy and abdominal computed tomography. Laparoscopic partial cecum resection was performed. Pathology examination revealed foci of endometriosis externa, which infiltrated the muscular layer of the appendix. Al should be kept in mind in the differential diagnosis of recurrent abdominal pain. Colonoscopy is an indispensable examination for differential diagnosis. Laparoscopic partial cecum resection, preserving the ileocecal valve, is an appropriate treatment approach in irreducible cases that are not suspected to be malignant.
\end{abstract}

Key words: Appendix, intussusception, laparoscopy

Cite this article as: Zenger S, Bilgiç Ç, Buğra D. Laparoscopic partial cecum resection in appendix intussusception. Turk J Surg 2019; 35 (1): 74-77

Corresponding Author Serkan Zenger

E-mail: serkanzen@hotmail.com

Received: 27.10 .2016

Accepted: 09.08.2017

Available Online Date: 28.18.2018

O Copyright 2019 by Turkish Surgical Society Available online at www.turkjsurg.com

DOI: $10.5578 /$ turkjsurg.3633

\section{INTRODUCTION}

Appendiceal intussusception (Al), which is one of the rare types of intussusception, is seen in $0.01 \%$ of the patients who undergo appendectomy (1). Anatomical changes such as partially mobile meso-appendix or large proximal appendicular lumen may be the cause of Al. Appendiceal intussusception-related symptoms include lower abdominal pain, irregular defecation, nausea, vomiting, or rectal hemorrhage. Making a preoperative diagnosis of Al is quite difficult, and usually a computed tomography (CT) of the abdomen and colonoscopy are required (2). The aim of this study was to report a case of Al, secondary to endometriosis, on whom laparoscopic partial cecum resection was performed, preserving the ileocecal valve.

\section{CASE REPORT}

A 35-year-old female patient presented to the general surgery outpatient clinic with lower abdominal pain, nausea, and vomiting persisting for the past one week. The patient did not have any defecation problems, did not describe weight loss, altered defecation habit, or urinary tract complaints but had a history of left oophorectomy performed due to endometriosis 6 years ago.

On physical examination, the patient was hemodynamically stable. There was no abdominal distention. Tenderness was found in the right lower quadrant, and a palpable mass could be detected on deep palpation. No defense or rebound was determined. Rectal examination was normal. Intestinal sounds were active. Routine blood tests demonstrated C-reactive protein (CRP) of $16 \mathrm{mg} / \mathrm{L}$, white blood cell count of $8490 / \mathrm{mm}^{3}$, hemoglobin of $9.5 \mathrm{~g} / \mathrm{dL}$, hematocrit of $31 \%$, and platelet count of $340.000 / \mathrm{mm}^{3}$.

A polypoid mass lesion measuring $3 \times 2.5 \mathrm{~cm}$, protruding toward the cecum lumen in the right lower quadrant, was detected on abdominal CT (Figure 1). On colonoscopic examination, a mass lesion, which had exudative and necrotic fields, appearing as the appendix, protruding into the cecum was detected at the appendix root site (Figure 2). Pathology of the colonoscopic biopsy revealed that the findings could be related to gangrenous appendicitis and also an inflammatory condition involving the ileocecal region. 


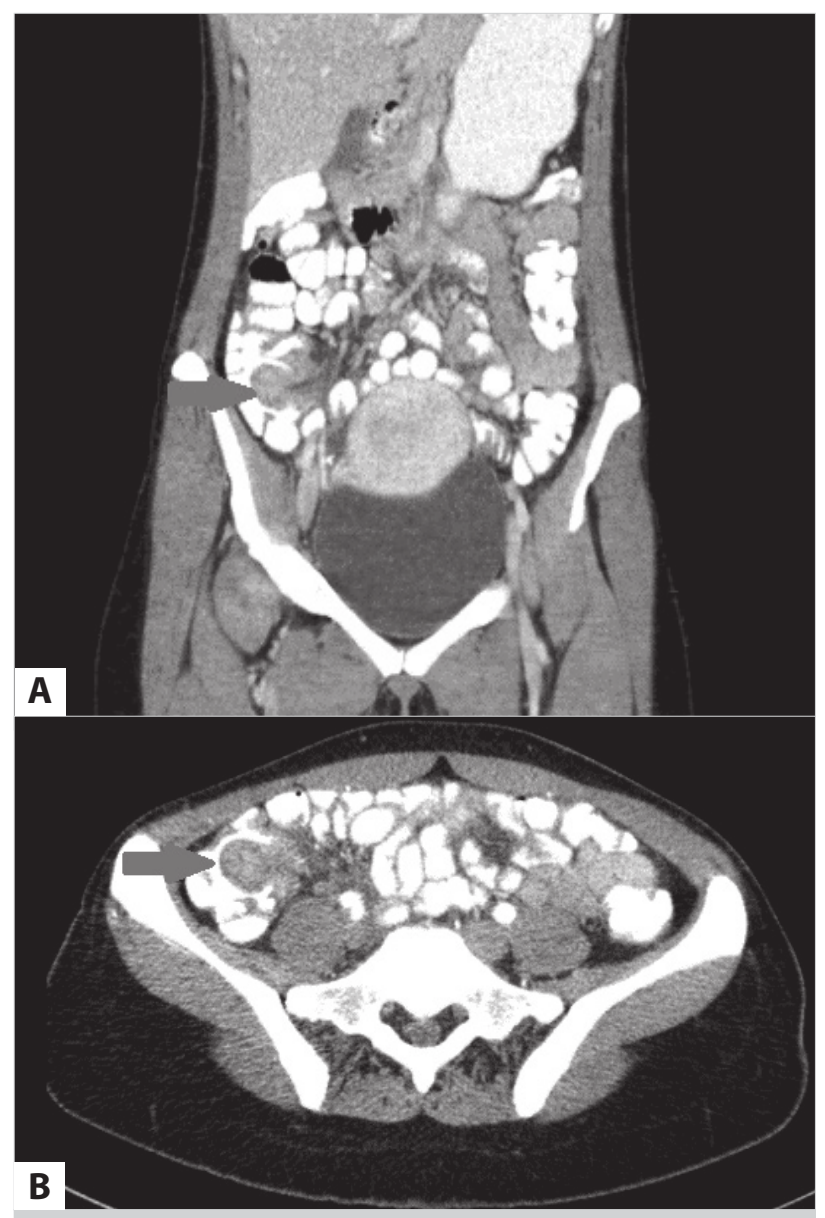

Figure 1 (A,B). Coronal (A) and axial (B) CT images of Al.

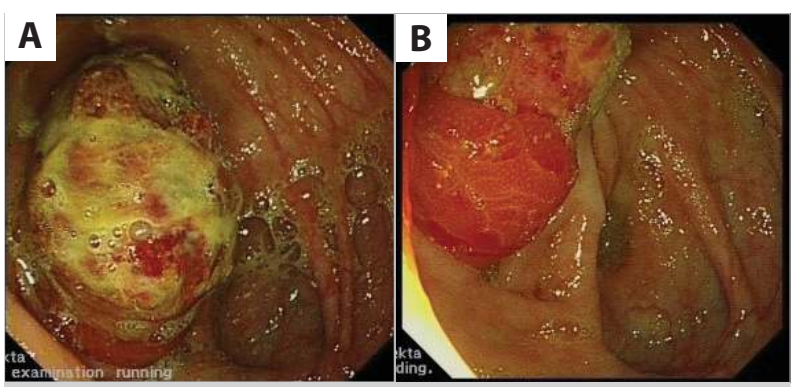

Figure $2(\mathbf{A}, \mathbf{B})$ Colonoscopy images of $\mathrm{Al}$.

Laparoscopic surgery was planned with a preliminary diagnosis of Al. The patient was informed that different interventions could be applied if needed during the operation. Verbal and written informed consent were obtained from the patient. First, diagnostic laparoscopy was performed. On exploration, the appendix was found to be completely inverted into the cecum (Figure 3). After having decided that the inverted appendix could not be reduced, laparoscopic partial cecum resection was performed, preserving the ileocecal valve (Figure 4).

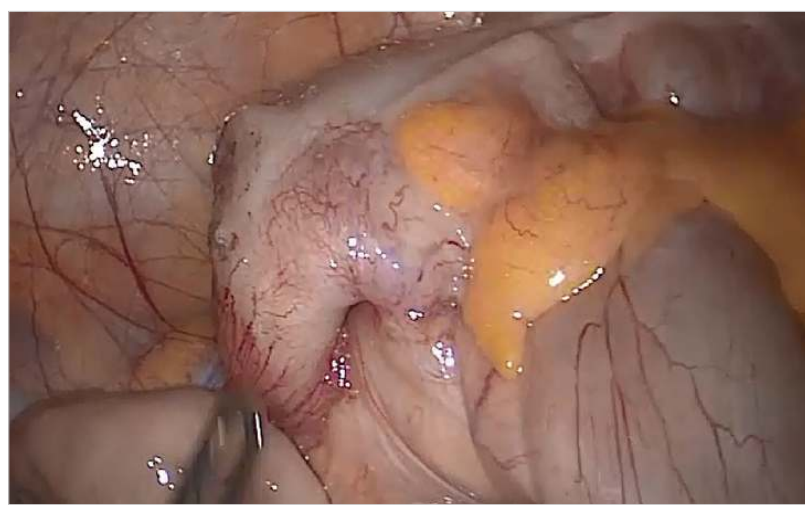

Figure 3. Intraoperative image of inverted appendix.

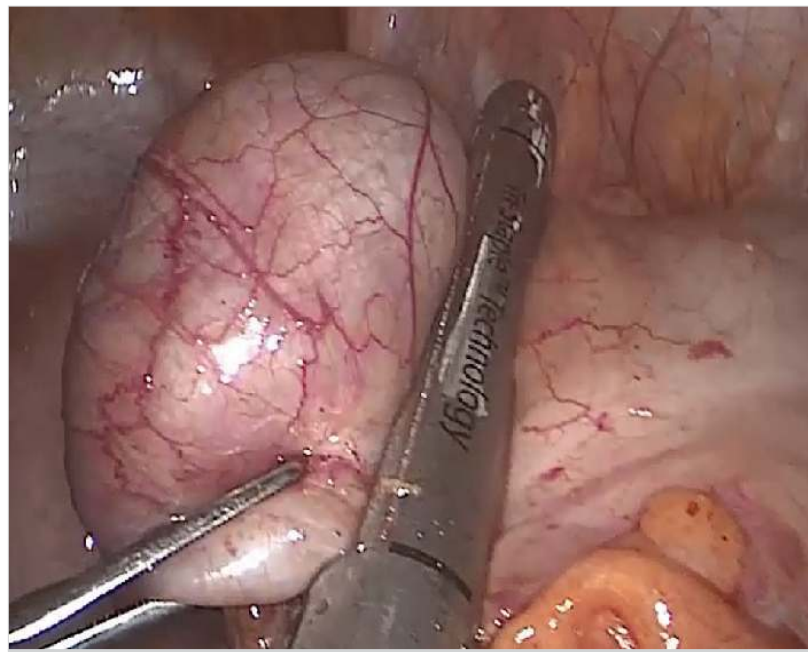

Figure 4. Intraoperative image of laparoscopic partial cecum resection.

The patient was followed in the hospital for 3 days without any complications. No complications developed during the postoperative 30 days. Foci of endometriosis externa infiltrating the muscular layer were detected on histopathological examination.

Laparoscopic surgery was planned with the pre-diagnosis of Al. The patient was informed that different interventions could be applied if needed during the operation. Verbal and written informed consent was obtained from the patient. First, diagnostic laparoscopy was performed. On exploration, the appendix was found to be completely inverted into the cecum (Figure 3). After having decided that the inverted appendix could not be reduced, laparoscopic partial cecum resection was performed, preserving the ileocecal valve (Figure 4).

The patient was follewed in the hospital for 3 days without any complications. No complications developed during the postoperative 30 days. Foci of endometriosis externa infiltrating the muscular layer were detected on the histopathological examination. 


\section{DISCUSSION}

$\mathrm{Al}$ is a rare condition. It was first reported by McKidd in 1858 (3). Collins have reported the incidence of $\mathrm{Al}$ as $0.01 \%$ as a result of the study conducted with 71.000 patients suffering appendicitis over the course of 40 years (4). Chaar et al. have reported in his study investigating $191 \mathrm{Al}$ cases that $76 \%$ of the cases were adult and $24 \%$ were children (2).

Anatomical changes such as partially mobile meso-appendix or large proximal appendicular lumen may be the cause of Al. While inflammation is the most common cause of $\mathrm{Al}$ in children, endometriosis is the most common cause in adults $(2,5,6)$. Other common causes include mucocele, adenoma, carcinoid, and adenocarcinoma (7-14). Papilloma, hamartoma, juvenile polyp, Crohn's disease, and melanosis coli are rare causes of Al (15-18).

Endometriosis is a common disease, which affects approximately $15 \%$ of the menstruating women in the United States. In the review of Robert et al. including 29 studies, appendix endometriosis has been reported in 336 out of 87.343 patients (0.4\%) undergoing appendectomy (19).

Four different clinical types of Al have been reported. The first type mimics the classical type of acute appendicitis. The second type shows typical intussusception signs, which include abdominal pain and sometimes vomiting, accompanied by diarrhea and melena. The third type has signs and symptoms such as melena, vomiting, and recurrent right lower quadrant pain that can persist for weeks or months. The forth type includes patients who are completely asymptomatic (20). The most common signs are abdominal pain (78\%), vomiting (26\%), and rectal hemorrhage (23\%). A mass lesion is detected in the right lower quadrant in 13\% of adult patients and $37 \%$ of pediatric patients (2).

Preoperative diagnosis of $\mathrm{Al}$ is difficult. It is made postoperatively in many cases (57\%). Diagnosis is made with postoperative pathological examination in $11 \%$ of the cases. Consequently, correct preoperative diagnosis has been made in only $32 \%$ of the cases (2). Barium contrast studies and abdominal ultrasonography have a limited value in the diagnosis of this rare condition. Abdominal CT is the most common imaging method. Colonoscopy is a very useful method in the diagnosis of Al in cases with abdominal pain and suspicious imaging findings (21). Our patient was evaluated with abdominal CT and the diagnosis was made with colonoscopy.

Different approaches have been used in the treatment of Al. Despite reports of successful colonoscopic appendectomy using the endo-loop ligation system, this approach may be harmful in patients who have partial intussusception (22-24). Spontaneously reduced $\mathrm{Al}$ cases have also been reported in the literature (25).

A total of 191 cases have been analyzed in one of the largest series in the literature, and appendectomy has been reported as the most common intervention (42\% in adults, $71 \%$ in children). lleocecectomy (27\%) and right hemicolectomy (21\%) have been performed in the remaining patients. Treatment with colonoscopy has been reported in four adult patients (3\%) (2). While appendectomy is sufficient in cases with only intussusception, right hemicolectomy is more appropriate for patients who are suspected to have neoplasia $(26,27)$. In our case, laparoscopic partial cecum resection was perfomed, preserving the ileocecal valve, as appendix reduction was not possible.

\section{CONCLUSION}

Preoperative diagnosis of $\mathrm{Al}$, which is a rare condition, is important. We consider that laparoscopic partial cecum resection through preservation of the ileocecal valve anatomy is an appropriate approach in patients who are not suspected to have malignancy and whose appendix cannot be reduced.

Informed Consent: Verbal informed consent was obtained from the patient.

Peer-review: Externally peer-reviewed

Author Contributions: Concept - S.Z., Ç.B., D.B.; Design - S.Z., Ç.B.; Supervision - D.B.; Resource - S.Z., Ç.B., D.B.; Materials - S.Z., Ç.B., D.B.; Data Collection and/or Processing - S.Z., Ç.B., D.B.; Analysis and/or Interpretation - S.Z., Ç.B., D.B.; Literature Search - S.Z., Ç.B., D.B.; Writing Manuscript - S.Z., Ç.B., D.B.; Critical Reviews - D.B.

Conflict of Interest: The authors have no conflicts of interest to declare.

Financial Disclosure: The authors declared that this study has received no financial support.

\section{REFERENCES}

1. Langsam LB, Raj PK, Galang CF. Intussusception of the appendix. Dis Colon Rectum 1984; 27: 387-92. [CrossRef]

2. Chaar Cl, Wexelman B, Zuckerman K, Longo W. Intussusception of the appendix: comprehensive review of the literature. Am J Surg 2009; 198: 122-8. [CrossRef]

3. McKidd J. Case of invagination of caecum and appendix. Edinburgh Med J 1858; 4: 793-7.

4. Collins D. Seventy one thousand human appendix specimens. A final report summarising forty years'study. Am J Proctol 1963; 14: 356-81.

5. Moradi P, Barakate M, Gill A, Farrow G. Intussusception of the veriform appendix due to endometriosis presenting as acute appendicitis. ANZ J Surg 2007; 77: 758-60. [CrossRef]

6. Duncan JE, DeNobile JW, Sweeney WB. Colonoscopic diagnosis of appendiceal intussusception: case report and review of the literature. JSLS 2005; 9: 488-90. [CrossRef]

7. Blondiaux E, Savoye-Collet C, Foulatier O, Lemoine F, Dacher JN. Appendiceal intussusception caused by a mucocele of the appendix: imaging findings. Digest Liver Dis 2007; 39: 1087. [CrossRef]

8. Waseem T, Javaid-ur-Rehman, Sabir NU, Hussain S, Amir E, Arif S. Rare association: Ileocaeco-colic intussusception secondary to mucinous cystadenoma of the appendix in an adult. ANZ J Surg 2007: 77: 1021-2. [CrossRef]

9. Kawamura YJ, Toyama N, Kasamatsu T, Ota M, Konishi F. Intussusception of appendiceal adenoma mimicking invasive carcinoma. Endoscopy 2002; 34: 749. [CrossRef]

10. Mathew J, Aldean IM, Ghafar FA, Haboubi NY. Appendicular intussusception into a polyp. Tech Coloproctol 2004; 8: 113-5. [CrossRef] 
11. Larsen SG, Nilssen A, Helseth A, Bohler P, Giercksky KE. Invagination of the appendix with carcinoid tumour. Eur J Surg 1999; 165: 993-7. [CrossRef]

12. Butte JM, Torres J, Henriquez IM, Pinedo G. Appendicular mucosal in tussusception into the cecum secondary to an intramural mucinous cystoadenoma of the appendix. J Am Coll Surg 2007; 204: 510. [CrossRef]

13. Takahashi M, Sawada T, Fukuda T, Furugori T, Kuwano H. Complete appendiceal intussusception induced by primary appendiceal adenocarcinoma in tubular adenoma: a case report. Jpn J Clin Oncol 2003; 33: 413-5. [CrossRef]

14. Thomas RE, Maude K, Rotimi O. A case of an intussuscepted neuroendocrine carcinoma of the appendix. World J Gastroenterol 200614; 12: 971-3. [CrossRef]

15. Goodwin DP. Intussusception due to hamartoma. Br Med J 1967; 4: 681-2. [CrossRef]

16. Bailey DJ, Courington KR, Andres JM, Bagwell CE, Hitchcock CL. Cecal polyp and appendiceal intussusception in a child with recurrent abdominal pain: diagnosis by colonoscopy. J Pediatr Gastroenterol Nutr 1987; 6: 818-20. [CrossRef]

17. Solomon DJ, Freson M, Price SK. Complete appendicular inversion: the "inside-out" appendix. An unusual presentation of Crohn's disease. A case report and review of the literature. J Belge Radiol 1991; 74: 115-6.

18. Akbayir N, Yildirim S, Sokmen HM, Kiliç G, Alkim C. Intussusception of vermiform appendix with microscopic melanosis coli: a case report. Turk J Gastroenterol 2006; 17: 233-5.

19. Gustofson RL, Kim N, Liu S, Stratton P. Endometriosis and the appendix: a case series and comprehensive review of the literature. Fertil Steril 2006; 86: 298-303. [CrossRef]
20. Reijnen JA, Festen C, Joosten HJ. Chronic intussusception in children. Br J Surg 1989; 76:815-6. [CrossRef]

21. Tavakkoli H, Sadrkabir SM, Mahzouni P. Colonoscopic diagnosis of appendiceal intussusception in a patient with intermittent abdominal pain: A case report. World J Gastroenterol 2007; 13: 4274-7. [CrossRef]

22. De Hoyos A, Monroy MA, Gallegos C, Checa G. Intussusception of the appendix resected at colonoscopy. Endoscopy 2006; 38: 763. [CrossRef]

23. Sriram PV, Seitz U, Soehendra N, Schroeder S. Endoscopic appendectomy in a case of appendicular intussusception due to endometriosis, mimicking a cecal polyp. Am J Gastroenterol 2000; 95: 1594-6. [CrossRef]

24. Pardoll PM, Wilcoxen JK, Trudeau WL. Primary asymptomatic appendiceal intussusception: a colonoscopic view. Gastrointest Endosc 1976; 23: 44. [CrossRef]

25. Komine N, Yasunaga C, Nakamoto M, Shima I, Iso Y, Takeda Y, et al. Intussusception of the appendix that reduced spontaneously during follow-up in a patient on hemodialysis therapy. Intern Med 2004; 43: 479-83. [CrossRef]

26. Miyahara M, Saito T, Etoh K, Shimoda K, Kitano S, Kobayashi M, et al. Appendiceal intussusception due to an appendiceal malignant polyp-an association in a patient with Peutz-Jeghers syndrome: report of a case. Surg Today 1995; 25: 834-7. [CrossRef]

27. Sadahiro S, Ohmura T, Yamada Y, Saito T, Akatsuka S. A case of cecocolic intussusception with complete invagination and intussusception of the appendix with villous adenoma. Dis Colon Rectum 1991; 34:85-8. [CrossRef]

\title{
OLGU SUNUMU-ÖZET
}

Turk J Surg 2019; 35 (1): 74-77

\section{Apendiks intususepsiyonunda laparoskopik parsiyel çekum rezeksiyonu}

\author{
Serkan Zenger ${ }^{1}$, Çağrı Bilgiç ${ }^{1}$, Dursun Buğra ${ }^{1,2}$ \\ ${ }^{1}$ VKV Amerikan Hastanesi, Genel Cerrahi Kliniği, İstanbul, Türkiye \\ ${ }^{2}$ Koç Üniversitesi Tıp Fakültesi, Genel Cerrahi Anabilim Dalı, İstanbul, Türkiye
}

\section{ÖZET}

Apendiks intususepsiyonu klinik tanısı zor bir hastalıktır. Bu olgu sunumunda karın ağrısı nedeniyle başvuran ve apendiks intususepsiyonu tanısı ile tedavi edilen 35 yaşındaki kadın hasta vesilesiyle, hastalığın değişik yönleri incelenmiştir. Tanı kolonoskopi ve karın tomografisi ile konuldu. Laparoskopik parsiyel çekum rezeksiyonu uygulandı. Patolojik değerlendirmede apendiksin kas tabakasına infiltre olan endometriozis eksterna odakları tespit edildi. Apendiks intususepsiyonu tekrarlayıcı karın ağrısının ayırıcı tanısında düşünülmelidir. Kolonoskopi ayıııcı tanıya ulaşmada vazgeçilemez bir incelemedir. Redükte edilemeyen ve malignite şüphesi olmayan olgularda, ileoçekal valvi koruyarak laparoskopik parsiyel çekum rezeksiyonu uygun bir tedavi yaklaşımıdır.

Anahtar Kelimeler: Apendiks, intususepsiyon, laparoskopi

Doi: 10.5578/turkjsurg.3633 